\title{
REGIONAL AND WATERSHED-SCALE COHERENCE IN THE STABLE-OXYGEN AND CARBON ISOTOPE RATIO TIME SERIES IN TREE RINGS OF COAST REDWOOD (SEQUOIA SEMPERVIRENS)
}

\author{
JOHN S. RODEN ${ }^{1 *}$, JAMES A. JOHNSTONE ${ }^{2,3}$, and TODD E. DAWSON ${ }^{2}$ \\ ${ }^{1}$ Department of Biology, Southern Oregon University, Ashland, OR, 97520, USA \\ ${ }^{2}$ Department of Integrative Biology, University of California, Berkeley, CA, 97420, USA
}

\begin{abstract}
Coast redwood (Sequoia sempervirens) ecosystems are strongly influenced by the presence of summer marine fog, and variation in fog frequency is closely linked to climate variation in the NE Pacific region. Because oxygen isotope composition $\left(\delta^{18} \mathrm{O}\right)$ of organic matter records distinct water sources (e.g. summertime fog vs. winter precipitation) and carbon isotopes $\left(\delta^{13} \mathrm{C}\right)$ are typically sensitive to humidity and water status, it then follows that inter-annual variation in tree-ring isotope ratios, which are coherent across multiple sites, should preserve a potentially powerful proxy for climate reconstruction. Here we present an analysis of a 50 -year time series for both $\delta^{18} \mathrm{O}$ and $\delta^{13} \mathrm{C}$ values from subdivided tree rings obtained from multiple redwood trees at multiple sites. Within-site and betweensite correlations were highly significant $(\mathrm{p}<0.01)$ for the $\delta^{18} \mathrm{O}$ time series indicating a regionally coherent common forcing of $\delta^{18} \mathrm{O}$ fractionation. Within-site and between-site correlation coefficients were lower for the $\delta^{13} \mathrm{C}$ than for the $\delta^{18} \mathrm{O}$ time series although most were still significant (at least to $\mathrm{p}<$ 0.05). The hypothesized reason for the differences in the correlation is that carbon isotope discrimination is more sensitive to microenvironmental and tree-level physiological variation than is $\delta^{18} \mathrm{O}$ fractionation. Stable-isotope variation in tree-ring cellulose was similar between slope, gully and riparian micro-habitats within a single watershed, implying that minor topographic variation when sampling should not be a major concern. These results indicate that stable-isotope time series from redwood tree rings are strongly influenced by regional climate drivers and potentially valuable proxies for Pacific coastal climate variability.
\end{abstract}

Keywords: Annual rings, $\delta^{18} \mathrm{O}, \delta^{13} \mathrm{C}$, cellulose, inter-annual variation, latewood.

\section{INTRODUCTION}

Coast redwood (Sequoia sempervirens D. Don) ecosystems are limited to a long ( $c a$. $750 \mathrm{~km}$ ) and narrow (e.g. within $50 \mathrm{~km}$ of the Pacific Ocean) region of central and northern California that experiences heavy marine fog during summer (Oberlander 1956). By frequently saturating the canopy atmosphere, fog has strong effects on redwood transpiration rates, as shown by short-term physiological monitoring (Burgess and Dawson 2004; Ewing et al. 2009; Johnstone

\footnotetext{
${ }^{3}$ Present address: Joint Institute for the Study of the Atmosphere and Ocean, University of Washington, Seattle, WA, 98105, USA.

*Corresponding author: rodenj@sou.edu; Telephone 541552-6798; Fax 541-552-6415
}

and Dawson 2010). Dawson (1998) estimated that mature redwood forests obtain between $22-46 \%$ of their yearly water input from fog drip, which can further affect tree water balance (Azevedo and Morgan 1974; Huntley et al. 1997; Simonin et al. 2009). Redwood tree crowns and forest canopies can effectively strip moisture from fog (Azevedo and Morgan 1974; Burgess and Dawson 2004) where it can either drip into the surrounding soils or be retained and taken up directly through plant leaves (Burgess and Dawson 2004). Climate variations that alter either the fraction of fog water utilized by plants or the frequency and intensity of fog events can impact redwood forest hydrologic processes. In fact, Johnstone and Dawson (2010) have shown that inter-annual variability of summer fog frequency displays 
coherence across the length of the coast redwood region. Moreover, summer fog frequency is related to a variety of interacting climatic factors, such as the summertime maximum temperature difference between coastal and inland locations, the coastal inversion strength, North Pacific sea surface temperatures, the magnitude of coastal alongshore winds, and therefore the marine upwelling system of the California Current. If the coastal oceanatmosphere system is modified, then the frequency of summertime fog events that influence redwood trees should change as well (Johnstone and Dawson 2010). In turn, if wintertime precipitation inputs increase or decline, then the fractional importance of fog as a water source will be oppositely affected. During a drier-than-normal year, Dawson (1998) found that redwood trees became more dependent on fog water inputs as other water sources became exhausted.

The stable-oxygen and hydrogen isotope compositions $\left(\delta^{18} \mathrm{O}\right.$ and $\left.\delta^{2} \mathrm{H}\right)$ of meteoric water, fog and tree sap are valuable tools for assessing hydrologic inputs as fog, which is isotopically distinct from rainfall (Gonfiantini and Longinelli 1962; Aravena et al. 1989; Ingraham and Matthews 1995; Dawson 1998). Through a series of known fractionation events, $\delta^{18} \mathrm{O}$ (and $\delta^{2} \mathrm{H}$ ) variation derived from hydrologic inputs is incorporated into the organic matter that makes up tree rings (Yapp and Epstein 1982; White et al. 1994; Roden and Ehleringer 1999b; Roden et al. 2000; Treydte et al. 2006; Gessler et al. 2009). Tree-ring cellulose $\delta^{18} \mathrm{O}$ values can be modified by variation in atmospheric humidity and the unique isotope values it possesses, by vapor pressure deficit and therefore the magnitude of leaf evaporative enrichment associated with transpiration (Edwards and Fritz 1986; Roden and Ehleringer 1999a; Wright and Leavitt 2006; Kahmen et al. 2008), by variation in source water (Wright et al. 1999; Roden and Ehleringer 1999b, 2007) and by post-photosynthetic but pre-biosynthetic factors shown to dampen the original isotope values of sucrose made at the leaf-level before it becomes incorporated into tree-ring cellulose (Brandes et al. 2006). Carbon isotope ratios $\left(\delta^{13} \mathrm{C}\right)$ in tree-ring cellulose have been used to study historical variations in plant water status, temperature, solar radiation and vapor pressure deficit (Saurer et al. 1995; Stewart et al. 1995; Hemming et al. 1998; Schleser et al. 1999; Barbour et al. 2002; Leavitt et al. 2002; Young et al. 2010). The mechanistic foundations for variation in cellulose $\delta^{13} \mathrm{C}$ and $\delta^{18} \mathrm{O}$ are now fairly well established (Farquhar et al. 1982, 1989; Roden et al. 2000; Barbour et al. 2004). Thus, absolutely dated time series of $\delta^{18} \mathrm{O}$ and $\delta^{13} \mathrm{C}$ variation in redwood tree rings have the potential to provide valuable historical records of climate variation and fog water utilization.

Previously, we found that redwood tree rings exhibit substantial intra-annual variation in both $\delta^{18} \mathrm{O}$ and $\delta^{13} \mathrm{C}(>3$ and $2 \%$, respectively, Roden $e t$ al. 2009). The latewood portion of the ring produced the most enriched (in ${ }^{18} \mathrm{O}$ ) cellulose whereas the most depleted $\delta^{18} \mathrm{O}$ values were found in the center of the ring. We termed this location "middlewood" as a positional designator (rather than a seasonal one) so as not to confuse it with earlywood. Earlywood spans a large portion of the annual ring, and it is not isotopically uniform (Barbour et al. 2002; Poussart et al. 2004; Roden et al. 2009). A number of studies have confirmed that the first cells produced in spring (initial earlywood) have isotope values related to the previous summer's environment and thus may represent a mixture of environmental conditions (Ogle and McCormac 1994; Hill et al. 1995; Kagawa et al. 2005, 2006). For redwood, Roden et al. (2009) speculated that the dip in $\delta^{18} \mathrm{O}$ in the middlewood portion of the annual growth ring represents the time when stored carbohydrates from the previous year have been fully exhausted and thus represents the truest spring environmental signal. Although not as consistent in their patterns, $\delta^{13} \mathrm{C}$ also showed significant intraannual variation in redwood (Roden et al. 2009, see also Loader et al. 1995; Schleser et al. 1999; Warren et al. 2001). Thus when sampling longer chronologies, we chose to sample the two portions of the annual ring that produced the greatest intraannual differences (latewood and middlewood).

Before inter-annual variation in $\delta^{18} \mathrm{O}$ and $\delta^{13} \mathrm{C}$ time series of redwood tree rings can be interpreted as proxies for regional climate variability, we must clarify whether such variation is spatially coherent and at what scale. If inter- 
annual isotopic variation is not coherent between trees at the same site, then these signals would be of limited use as proxies for any environmental factor. Physiological differences between trees can influence isotopic fractionation, and their ability to dampen climate signals may be an important limitation of this technique. If, however, they are coherent locally but not regionally then climate drivers are likely to be related to microclimate rather than larger scale meteorological patterns (Leavitt et al. 2002). These questions require significant replication of trees and sites and analysis of a long enough time series to be able to assess the viability of this system for paleoclimatic reconstruction. Analyzing many years of annual growth rings on a few trees may not provide the information necessary to indicate that those signals represent anything more than microclimatic variation. Within-site and between-site coherence in the stable-isotope variation in tree-ring time series have been reported for other species (Leavitt and Long 1988, 1989; McCarroll and Pawellek 2001; Roden and Ehleringer 2007). In addition, it is important to determine if specific locations at any site are more sensitive to climate variation than others. For example, organic matter $\delta^{18} \mathrm{O}$ values are primarily influenced by source water $\delta^{18} \mathrm{O}$ variation of meteoric waters (Roden and Ehleringer 1999b; Robertson et al. 2001). However, if a tree obtains most of its water from a perennial stream because of its location in the riparian zone, then it may not be sensitive to changes in meteoric water $\delta^{18} \mathrm{O}$. Because fog water is captured as it moves across the landscape, it is important to determine if geographic features (e.g. slope, aspect) influence uptake of this hydrologic resource. All of these considerations are necessary to develop sampling strategies for optimizing the potential of long-term tree-ring time series to serve as valuable proxies for past climate variation.

Annual differences in hydrologic inputs and environmental conditions are potential drivers of inter-annual variability in cellulose $\delta^{18} \mathrm{O}$ and $\delta^{13} \mathrm{C}$ for redwood tree rings (Roden et al. 2009). The objective of this study was to determine if there is coherence in the latewood and middlewood variation of $\delta^{18} \mathrm{O}$ and $\delta^{13} \mathrm{C}$ in redwood tree-ring cellulose over the last 50 years between replicate trees at multiple sites. A further objective was to determine if differences in tree location associated with geographic features within a single watershed produce differences in $\delta^{18} \mathrm{O}$ and $\delta^{13} \mathrm{C}$ values. We hypothesize that (1) redwood trees will display significant coherence in inter-annual $\delta^{18} \mathrm{O}$ and $\delta^{13} \mathrm{C}$ time series between trees at a single site and between trees at distant sites, implying that regional climate drivers may impact isotopic fractionation, and (2) local climate drivers or common forcing are more important than geographic influences producing consistent patterns of $\delta^{18} \mathrm{O}$ and $\delta^{13} \mathrm{C}$ variation within a watershed.

\section{METHODS}

\section{Site Locations, Descriptions and Sampling}

From 2002-2003, a minimum of four coast redwood trees (Sequoia sempervirens [D. Don] End1.) were sampled from four sites in Northern California (Figure 1). The most southerly site was the Sonoma site that is a Save-the-RedwoodLeague reserve called "Grove of the Old Trees" near Santa Rosa, CA $\left(38^{\circ} 24.0^{\prime} \mathrm{N} 122^{\circ} 59.5^{\prime} \mathrm{W}\right.$, elevation $220 \mathrm{~m}$ a.s.l. with relatively flat topography). Progressing northward, trees were also sampled at the Arcata Community Forest near Arcata, CA $\left(40^{\circ} 52.5^{\prime} \mathrm{N} 124^{\circ} 4.1^{\prime} \mathrm{W}\right.$, elevation $158 \mathrm{~m}$, on a gentle slope; in addition, a transect was sampled across an open slope to gully transition at this site), at Prairie Creek near Klamath, CA $\left(41^{\circ} 27.4^{\prime} \mathrm{N} 124^{\circ} 2.8^{\prime} \mathrm{W}\right.$, elevation $207 \mathrm{~m}$, situated on a slope facing the ocean), and Jedediah Smith near Hiouichi, CA $\left(41^{\circ} 47.3^{\prime} \mathrm{N}\right.$ $124^{\circ} 4.6^{\prime} \mathrm{W}$, elevation $42 \mathrm{~m}$, with flat topography). Both Prairie Creek and Jedediah Smith sites are part of the Redwood State and National Park system. These sites span a $300-\mathrm{km}$ latitudinal range of classic redwood habitat. All trees sampled were between 55 and $94 \mathrm{~cm}$ in diameter and would be classified as canopy subdominants. Trees were cored to obtain approximately the last 50 years of tree rings and because trees were not cored to the center, pith ages were not obtained and juvenile wood was not sampled. Four cores (12 mm diameter) were obtained from 


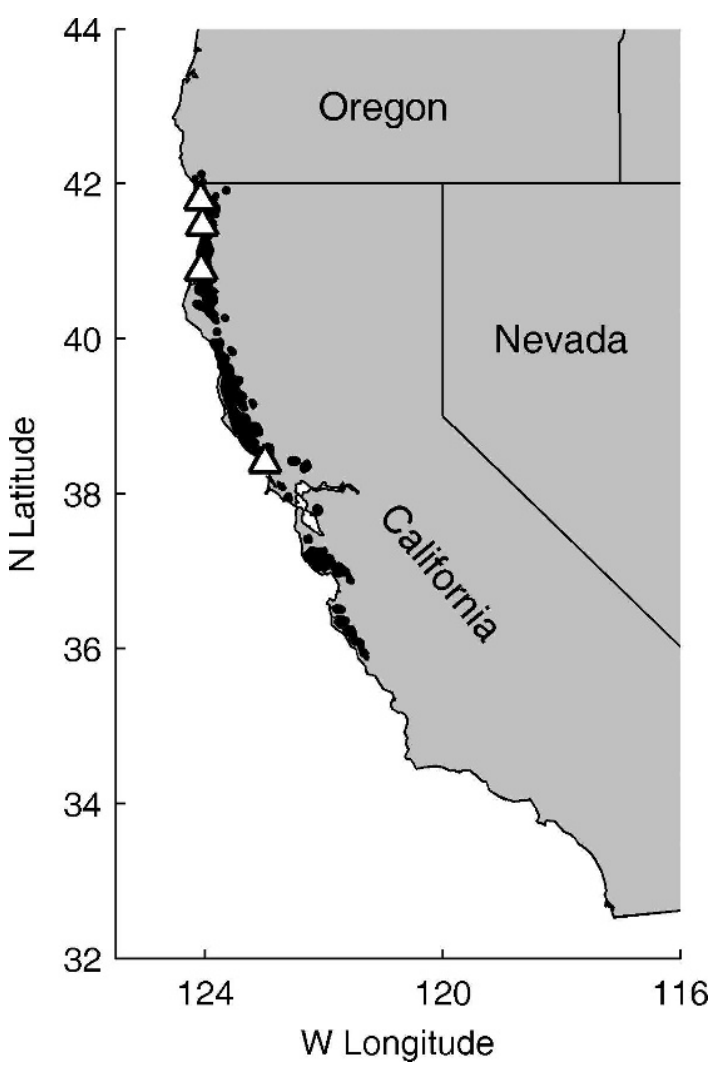

Figure 1. Site map showing the distribution of coast redwood ecosystems and sampling locations (open triangles; from north to south, Jedediah Smith, Prairie Creek, Arcata and Sonoma).

the four cardinal directions at breast height for each tree.

\section{Sample Processing}

The four cores from each tree were compared and examined for ring anomalies, and the estimated year (by ring counting) was marked with pinholes. Annual growth increments were measured to the nearest $0.01 \mathrm{~mm}$ on all cores on a micrometer stage. The ring-width time series were used for within-tree and between-tree crossdating using the COFECHA program (Holmes 1983; Grissino-Mayer 2001; Roden 2008). Because of the short chronology length, a 20-year spline length (without autoregressive modeling) and a 30 -year segment length with a 15-year overlap was utilized. The critical correlation coefficient $(99 \%$ confidence) for a 30-year segment length was
0.4226. All other default options in COFECHA (e.g. log transformations) were used for all runs. In general, if a tree could not be reliably crossdated with others at the site (or if the four within-tree cores could not be crossdated) the tree was not used for isotope analysis, reducing the number of samples from each site by 1 or 2 trees. Past research considered crossdating coast redwood to be problematic because of extensive ring anomalies (e.g. ring wedging, false latewood bands (Brown and Swetnam 1994)). However, ring anomalies are more prevalent in very large trees whereas these smaller trees were still rapidly growing and producing large rings (up to $10 \mathrm{~mm}$ wide), creating few ring-counting problems. The mesic environment of coastal California did produce complacent growth, which made crossdating less than ideal.

An initial study (Roden et al. 2009) subdivided redwood tree rings into 10 equal segments and found a consistent pattern in intra-annual variation in $\delta^{18} \mathrm{O}$ with the most enriched (in ${ }^{18} \mathrm{O}$ ) values found in the latewood portion (and in the initial earlywood formation of the next year) of the annual ring. The most depleted $\delta^{18} \mathrm{O}$ values occurred in the central portion of the ring. Although this portion is a component of earlywood, Roden et al. (2009) used the term "middlewood" to clarify that only the central part of the ring was sampled and not the entire earlywood fraction. Middlewood is a positional designator not a seasonal one because growth rates vary throughout the year. Thus, two portions of each ring were sampled in this study, the latewood (representing summer conditions with the potential for fog water inputs to impact the cellulose isotope ratios) and middlewood (representing spring conditions and the winter/spring recharge period when soil moisture is highest and the water is largely from cold winter storms). Each ring was subdivided into approximately four slivers using a scalpel under a $20 \times$ dissecting microscope. The latewood sample comprised a thin section within the region of visually dense cells and just inside the ring boundary. The middlewood sample comprised a thin section from the center of the ring and within the less dense earlywood portion. Other portions of the ring (e.g. the initial 
earlywood) were discarded. The thickness of each section depended on ring width, and because most ring widths were fairly large (from 2 to $10 \mathrm{~mm}$ ), subdividing only became problematic with the occasional very narrow ring. The two subdivisions from each core obtained from the four cardinal directions on each tree were pooled, dried at $70^{\circ} \mathrm{C}$ for $48 \mathrm{~h}$ and ground to a fine powder with a ball mill (Wig-L-Bug, Crescent, Elgin, Ill, USA).

\section{Cellulose Extraction}

The detailed description of cellulose extraction procedures is given in Roden et al. (2009). The procedure is modified from Leavitt and Danzer (1993; see also Gaudinski et al. 2005 for a methods comparison). Briefly, resins were extracted from the dried wood samples using organic solvents in a Soxhlet apparatus. Soluble sugars were extracted by boiling in water. Samples were "bleached" using a strong sodium chlorite/ acetic acid solution to remove lignin and other Ncontaining compounds. The resulting holocellulose was converted to $\alpha$-cellulose in a strong $\mathrm{NaOH}$ solution. The $\alpha$-cellulose was dried at $70^{\circ} \mathrm{C}$ for $48 \mathrm{~h}$.

\section{Analysis of Stable-Carbon and Oxygen Isotope Ratios}

As above, a description of isotope analysis procedures can be found in Roden et al. (2009). All isotope measurements were performed at the Center for Stable Isotope Biogeochemistry at the University of California, Berkeley. To measure cellulose $\delta^{18} \mathrm{O}$ a pyrolysis method (at $1,130^{\circ} \mathrm{C}$ ) modified from Farquhar et al. (1997) was utilized. From 0.9 to $1.1 \mathrm{mg}$ of $\alpha$-cellulose was analyzed for $\delta^{18} \mathrm{O}$ with a Thermo-Finnigan Delta Plus XL mass spectrometer (Bremen Germany). The system was calibrated with IAEA $\mathrm{C}_{3}$ cellulose at an oxygen isotope value of $32.2 \%$ ( $\delta^{18} \mathrm{O}$, VSMOW). Longterm average and external precision for the quality control IAEA V9 cotton cellulose is $28.62 \%$ o $\left(\delta^{18} \mathrm{O}\right.$ SMOW) with a standard deviation of $0.20 \%$ ( $\mathrm{n}=$ 96). Values are expressed in standard "delta notation" as $\delta=\left(\mathrm{R}_{\text {sample }} / \mathrm{R}_{\text {standard }}-1\right) \times 1,000$ in units of per mil (\%) or parts per thousand where $\mathrm{R}$ is the ratio of the rare $\left({ }^{18} \mathrm{O}\right)$ to common $\left({ }^{16} \mathrm{O}\right)$ isotope.

For $\delta^{13} \mathrm{C}$ measurements, approximately $1 \mathrm{mg}$ of $\alpha$-cellulose was loaded into tin capsules and combusted on an elemental analyzer (Carlo-Erba Model NS-1500, Milan, Italy) coupled to a PDZ Europa (20/20) isotope ratio mass spectrometer (Crewe, UK). Long-term average and external precision for the quality control $\alpha$-cellulose standards for $\delta^{13} \mathrm{C}$ was $0.17 \%$ with a standard deviation of $0.07 \%$ ( $\mathrm{n}>2,000$; years 2003-2007).

\section{Statistical Analysis of Time Series}

Pearson's correlation coefficients for each time-series comparison and analysis of variance (Univariate GLM) for transect comparisons were calculated using SPSS statistical software (version 15). In addition, because the COFECHA program (Holmes 1983; Grissino-Mayer 2001) was specifically developed to handle time-series correlations between multiple tree-ring data sets, we also ran our isotope time-series data through the COFECHA program (see above for details). We also calculated the expressed population signal (EPS, Briffa and Jones 1990; Robertson et al. 1997) as an estimate of signal strength. EPS $=(t \times r) \div((t \times$ $r)+(1-r))$, where $t$ is the number of time series associated with $r$, which is the mean inter-series correlation coefficient.

\section{RESULTS}

\section{Within-Site Coherence}

For both latewood and middlewood records, redwood trees growing at each site produced $\delta^{18} \mathrm{O}$ time series that were significantly correlated with each other $(p<0.01$, Table 1$)$. Not only were these time series coherent between trees at each site, but the absolute values were also quite similar. Although some years were more variable, the range in $\delta^{18} \mathrm{O}$ values for any year was often much less than 1\%o (Figure 2). Maximum interannual variation in $\delta^{18} \mathrm{O}$ was between 2 and $3 \%$ for both latewood and middlewood segments at each site (Figure 2; data not shown for other sites). The expressed population signal statistic (EPS, Table 1) attempts to quantify the strength 
Table 1. Summary statistics from between-tree isotope chronologies as derived from the COFECHA program. Also included is the expressed population signal for each between-tree comparison. The analysis was performed using time-series data from three to four trees from each site. Significant correlations are indicated by asterisks: ${ }^{* *} \mathrm{p}<0.01$; and ${ }^{*} \mathrm{p}<0.05$.

\begin{tabular}{|c|c|c|c|c|c|}
\hline & $\begin{array}{c}\text { Mean } \\
\text { Measurement (\%o) }\end{array}$ & $\begin{array}{c}\text { Mean } \\
\text { Correlation }\end{array}$ & $\begin{array}{c}\text { Mean } \\
\text { sensitivity }\end{array}$ & $\begin{array}{c}\text { Auto- } \\
\text { Correlation }\end{array}$ & $\begin{array}{c}\text { Expressed } \\
\text { Population Signal }\end{array}$ \\
\hline \multicolumn{6}{|c|}{ Sonoma site (1954-2002) } \\
\hline$\delta^{18} \mathrm{O}$ latewood & 31.7 & $0.669 * *$ & 0.030 & 0.112 & 0.890 \\
\hline$\delta^{13} \mathrm{C}$ latewood & -23.9 & $0.570^{* *}$ & 0.028 & 0.451 & 0.841 \\
\hline$\Delta^{13} \mathrm{C}$ latewood & 16.6 & $0.624^{* *}$ & 0.041 & 0.211 & 0.869 \\
\hline$\delta^{18} \mathrm{O}$ middlewood & 30.9 & $0.702 * *$ & 0.026 & 0.182 & 0.904 \\
\hline$\delta^{13} \mathrm{C}$ middlewood & -24.1 & $0.492^{* *}$ & 0.015 & 0.655 & 0.795 \\
\hline$\Delta^{13} \mathrm{C}$ middlewood & 16.8 & $0.482^{* *}$ & 0.021 & 0.426 & 0.788 \\
\hline \multicolumn{6}{|c|}{ Arcata site (1962-2004) } \\
\hline$\delta^{18} \mathrm{O}$ latewood & 28.4 & $0.760 * *$ & 0.016 & 0.421 & 0.905 \\
\hline$\delta^{13} \mathrm{C}$ latewood & -23.6 & $0.540^{* *}$ & 0.013 & 0.506 & 0.779 \\
\hline$\Delta^{13} \mathrm{C}$ latewood & 16.1 & $0.538^{* *}$ & 0.019 & 0.453 & 0.777 \\
\hline$\delta^{18} \mathrm{O}$ middlewood & 27.0 & $0.732^{* *}$ & 0.017 & 0.276 & 0.891 \\
\hline$\delta^{13} \mathrm{C}$ middlewood & -23.5 & $0.415^{*}$ & 0.010 & 0.727 & 0.680 \\
\hline$\Delta^{13} \mathrm{C}$ middlewood & 16.1 & $0.373^{*}$ & 0.015 & 0.461 & 0.641 \\
\hline \multicolumn{6}{|c|}{ Prairie Creek site (1953-2003) } \\
\hline$\delta^{18} \mathrm{O}$ latewood & 27.8 & $0.747 * *$ & 0.020 & 0.121 & 0.922 \\
\hline$\delta^{13} \mathrm{C}$ latewood & -25.1 & 0.264 & 0.013 & 0.726 & 0.589 \\
\hline$\Delta^{13} \mathrm{C}$ latewood & 17.8 & 0.262 & 0.018 & 0.413 & 0.587 \\
\hline$\delta^{18} \mathrm{O}$ middlewood & 27.3 & $0.628^{* *}$ & 0.016 & 0.129 & 0.871 \\
\hline$\delta^{13} \mathrm{C}$ middlewood & -24.9 & 0.269 & 0.013 & 0.743 & 0.595 \\
\hline$\Delta^{13} \mathrm{C}$ middlewood & 17.7 & 0.246 & 0.018 & 0.428 & 0.566 \\
\hline \multicolumn{6}{|c|}{ Jed Smith site (1952-2003) } \\
\hline$\delta^{18} \mathrm{O}$ latewood & 28.8 & $0.770^{* *}$ & 0.022 & 0.147 & 0.909 \\
\hline$\delta^{13} \mathrm{C}$ latewood & -24.4 & $0.625^{* *}$ & 0.018 & 0.378 & 0.833 \\
\hline$\Delta^{13} \mathrm{C}$ latewood & 17.2 & $0.622 * *$ & 0.026 & 0.435 & 0.832 \\
\hline$\delta^{18} \mathrm{O}$ middlewood & 28.5 & $0.735^{* *}$ & 0.022 & 0.031 & 0.893 \\
\hline$\delta^{13} \mathrm{C}$ middlewood & -24.6 & $0.381 *$ & 0.039 & 0.331 & 0.649 \\
\hline$\Delta^{13} \mathrm{C}$ middlewood & 17.3 & $0.469^{* *}$ & 0.018 & 0.626 & 0.726 \\
\hline
\end{tabular}

of common forcing and can be used to indicate the number of replicate time series required to obtain adequate climate signals. Although a specific significance value for EPS is not available, some have suggested (Wigley et al. 1984; Robertson et al. 1997) that an EPS exceeding 0.85 indicates an acceptable level of chronology confidence. EPS results indicate that three to four trees were sufficient to produce a strong common variance (implying common forcing) for all within-site comparisons of $\delta^{18} \mathrm{O}$ time series.

Within-site comparisons of $\delta^{13} \mathrm{C}$ time series produced lower correlations than $\delta^{18} \mathrm{O}$ time series (Table 1). Many within-site $\delta^{13} \mathrm{C}$ correlations were still statistically significant (at least to $\mathrm{p}<0.05$ ), except those from the Prairie Creek site. Although some within-site $\delta^{13} \mathrm{C}$ time series produced EPS values close to or exceeding 0.85, in general EPS values were lower for $\delta^{13} \mathrm{C}$ than $\delta^{18} \mathrm{O}$ time series (Table 1). It is unclear why the Prairie Creek site did not produce coherent time series. The power of the COFECHA program is in detecting dating errors by breaking the series into segments and testing if better correlations result if the sequences are moved in relation to the mean series. Although the program flagged some odd years for the Prairie Creek data set, there was no clear benefit of shifting years and thus we assumed that each series was correctly dated. A latewood $\delta^{13} \mathrm{C}$ time series from the Sonoma site produced significant within-site correlations (Figure 3A), whereas a middlewood time series from Prairie Creek (Figure $3 \mathrm{~B})$ did not. Within-year variation in $\delta^{13} \mathrm{C}$ values appear greater than for $\delta^{18} \mathrm{O}$ variation, with 


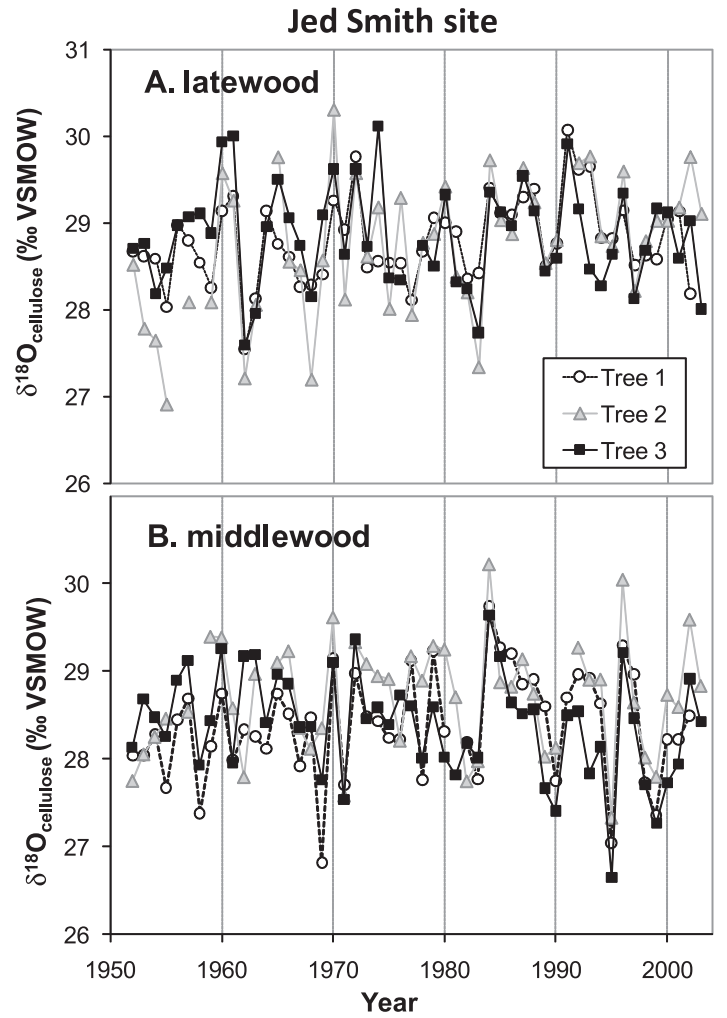

Figure 2. Latewood (A) and middlewood (B) $\delta^{18} \mathrm{O}$ time series for tree-ring cellulose in three replicate redwood trees from the Jedediah Smith site. Both latewood and middlewood series were significantly correlated ( $\mathrm{p}<0.01$, see Table 1$)$.

many years producing a between-tree range of $\delta^{13} \mathrm{C}$ values up to $2 \%$ (Figure 3 ). Maximum interannual variation in $\delta^{13} \mathrm{C}$ was between 1 and $3 \%$ for both latewood and middlewood segments at each site (Figure 3; data not shown for other sites).

Many $\delta^{13} \mathrm{C}$ time series produced lowerfrequency trends (Figure 3B) that were likely associated with changing concentration and $\delta^{13} \mathrm{C}$ values of atmospheric $\mathrm{CO}_{2}$ (Francey et al. 1999; McCarroll et al. 2009). To correct for this we calculated $\Delta{ }^{13} \mathrm{C}$ values for all time series: $\Delta{ }^{13} \mathrm{C}=$ $\left(\delta^{13} \mathrm{C}_{\text {source }}-\delta^{13} \mathrm{C}_{\text {product }}\right) /\left(1+\delta^{13} \mathrm{C}_{\text {product }}\right)$, where source is atmospheric $\mathrm{CO}_{2}$ and product in this case is cellulose (Farquhar et al. 1982). On occasion, using $\Delta^{13} \mathrm{C}$ rather than $\delta^{13} \mathrm{C}$ produced higher correlation coefficients, but often the differences were minimal (Table 1). This is likely because the COFECHA program removes nearly all low-
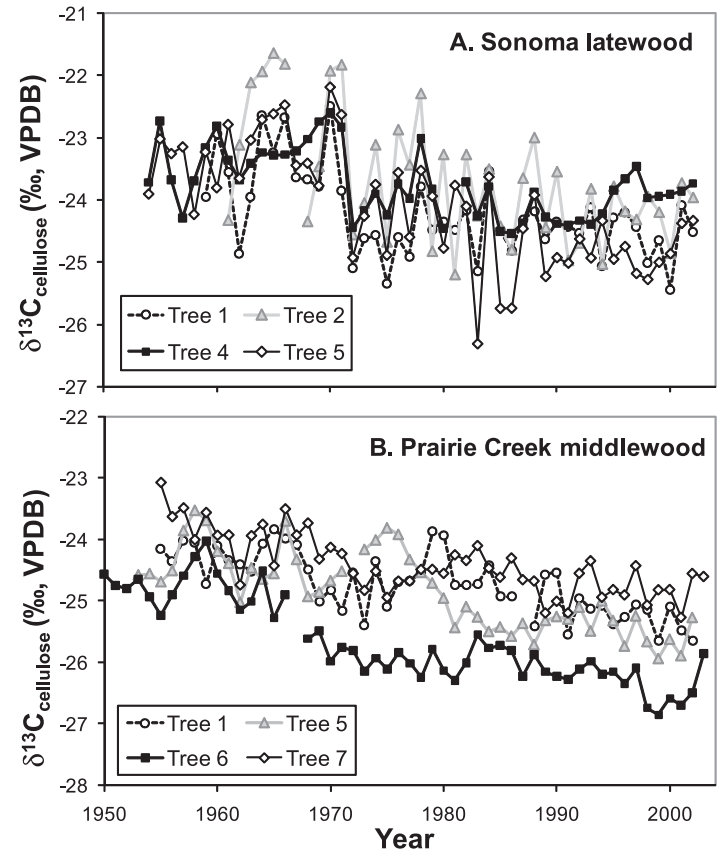

Figure 3. Latewood $\delta^{13} \mathrm{C}$ time series for tree-ring cellulose in four replicate redwood trees at the Sonoma site (A) and middlewood from the Prairie Creek site (B). The time series were significantly correlated ( $p<0.01$, see Table 1$)$ for the Sonoma site but not for the Prairie Creek site.

frequency trends via spline fitting, autoregressive modeling and $\log$ transformations (GrissinoMayer 2001) and $\Delta^{13} \mathrm{C}$ simply eliminates the trend using a different technique. Significant correlations result if Prairie Creek $\delta^{13} \mathrm{C}$ time series are analyzed with standard correlation analysis (not detrended or corrected for changes in $\delta^{13} \mathrm{C}$ of atmospheric $\mathrm{CO}_{2}$ ). This demonstrates the importance of correcting for low-frequency trends when determining coherence between isotope time series.

\section{Watershed Coherence}

The correlations above were performed on 3 to 4 trees per site, with each tree being in close proximity to the others (within $100 \mathrm{~m}$ ). To test for larger scale site variation, we measured 24 trees along a transect within one watershed at the Arcata site. Generating 50 years worth of isotope data on each tree would have been time consuming and expensive, thus we decided to focus on only 


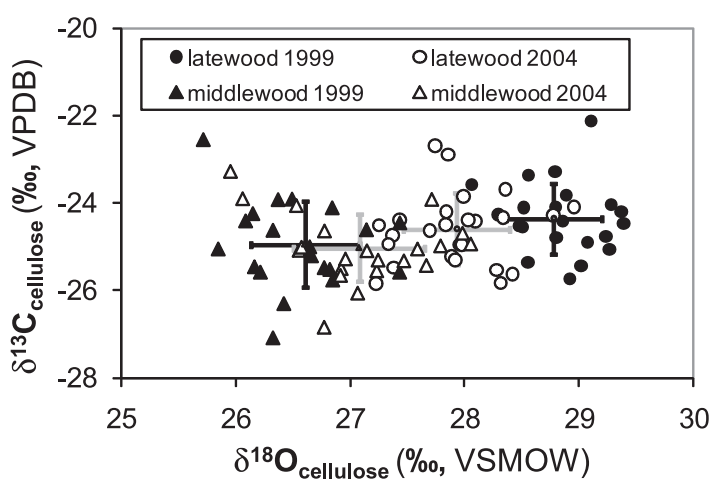

Figure 4. Middlewood and latewood carbon and oxygen stable isotope composition of tree-ring cellulose from 1999 and 2004 from 24 redwood trees within a single watershed at the Arcata site. The bars represent \pm 1 standard deviation for the mean values for each tree-ring subdivision and year.

two years $(1999,2004)$ that have been shown to produce very different latewood and middlewood values for $\delta^{18} \mathrm{O}$. Three distinct environments were tested along the transect: (1) trees on an open slope above the riparian gully, (2) trees within the gully but away from the stream, and (3) trees in close proximity to the stream (riparian). Although the $\delta^{18} \mathrm{O}$ and $\delta^{13} \mathrm{C}$ measurements were variable at each position, distinctions between the two years and between latewood and middlewood were generally maintained (Figure 4). Analysis of variance showed no significant differences between positions (data not shown) indicating that "noise" in the results as seen in Figure 4 was similar for each micro-site. There were no significant differences between the slope, gully and riparian locations for any measurements of $\delta^{13} \mathrm{C}$ or for latewood $\delta^{18} \mathrm{O}$ (Table 2). The only significant differences between tree locations were for middlewood $\delta^{18} \mathrm{O}$. Trees located in the gully, regardless of proximity to the stream, produced middlewood that was more enriched (in ${ }^{18} \mathrm{O}$ ) than trees located on the slope above the gully (Table 2).

\section{Between-Site Coherence}

The latewood and middlewood $\delta^{18} \mathrm{O}$ timeseries data (using mean values for each site) produced significant correlations between all four sites $(\mathrm{p}<0.01$, Table 3$)$. In addition, the timeseries difference between latewood and middlewood $\delta^{18} \mathrm{O}$ was also significantly correlated $(\mathrm{p}<$ 0.01 ). These data indicate a strong coherence of factors that influence $\delta^{18} \mathrm{O}$ variation in trees separated by over $300 \mathrm{~km}$. This tight coherence was observed despite significant differences in absolute $\delta^{18} \mathrm{O}$ values between sites. In general the more southerly (Sonoma) and inland (Jed Smith) sites produced more enriched (in ${ }^{18} \mathrm{O}$ ) values as compared to the more northerly and coastal sites (Prairie Creek and Arcata) for both latewood and middlewood (Figure 5). The high EPS values (Table 3) for between-site $\delta^{18} \mathrm{O}$ time series indicate adequate signal strength and the potential for common climate forcing for redwood trees at these regional scales.

The analysis for $\delta^{13} \mathrm{C}$ coherence, however, is not as conclusive. Latewood $\delta^{13} \mathrm{C}$ time series were significantly correlated ( $\mathrm{p}<0.05$ ), but middlewood was not (Table 3 ). These analyses were also performed on $\Delta^{13} \mathrm{C}$ values, but because this had no effect on the conclusions, the results are not presented (the COFECHA program already de-

Table 2. Mean and standard deviation (in parentheses) values for the stable isotope ratios of oxygen and carbon in tree-ring cellulose of coast redwood in a single watershed at the Arcata site. Significant differences $(\mathrm{p}<0.01)$ between tree positions (within the column) are indicated with asterisks.

\begin{tabular}{lrrrr}
\hline & Middlewood 1999 & Latewood 1999 & Middlewood 2004 & Latewood 2004 \\
\hline $\boldsymbol{\delta}^{\mathbf{1 8}} \mathbf{O}_{\text {cellulose (\%o,VSMOW) }}$ & & & \\
Slope (n =7) & $26.15^{* *}(0.31)$ & $28.89(0.40)$ & $26.59 * *(0.45)$ & $27.81(0.33)$ \\
Gully (n=10) & $26.72(0.40)$ & $28.75(0.49)$ & $27.17(0.38)$ & $27.93(0.55)$ \\
Riparian (n=7) & $26.90(0.41)$ & $28.69(0.33)$ & $27.50(0.60)$ & $28.04(0.53)$ \\
$\boldsymbol{\delta}^{\mathbf{1 3}} \mathbf{C}_{\text {cellulose (\%), PDB) }}$ & & & $-24.38(0.97)$ \\
Slope (n =7) & $-24.86(0.51)$ & $-23.94(0.98)$ & $-24.71(0.85)$ & $-24.43(0.81)$ \\
Gully (n=9) & $-25.17(1.05)$ & $-24.44(0.69)$ & $-25.29(0.73)$ & $-25.05(0.56)$ \\
Riparian (n=6) & $-25.18(0.88)$ & $-24.78(0.66)$ & $-24.99(0.72)$ & \\
\hline
\end{tabular}


Table 3. Summary statistics from between-site, isotope chronologies as derived from the COFECHA program. Also included is the expressed population signal for each between-site comparison. The analysis was performed on mean ( $\mathrm{n}=3$ to 4 trees) stable isotope values derived for each site. Significant correlations are indicated by asterisks: ${ }^{* *} \mathrm{p}<0.01$; and ${ }^{*} \mathrm{p}<0.05$.

\begin{tabular}{llccc}
\hline & & & & $\begin{array}{c}\text { Expressed } \\
\text { Population Signal }\end{array}$ \\
\hline All sites (1952-2003) & & & & \\
$\delta^{18} \mathrm{O}$ latewood & $0.635^{* *}$ & 0.019 & 0.565 & 0.874 \\
$\delta^{13} \mathrm{C}$ latewood & $0.367^{*}$ & 0.015 & 0.618 & 0.699 \\
$\delta^{18} \mathrm{O}$ middlewood & $0.604^{* *}$ & 0.017 & 0.122 & 0.859 \\
$\delta^{13} \mathrm{C}$ middlewood & 0.283 & 0.011 & 0.628 & 0.612 \\
$\delta^{18} \mathrm{O}$ latewood-middlewood & $0.633^{* *}$ & 0.240 & 0.125 & 0.873 \\
$\delta^{13} \mathrm{C}$ latewood-middlewood & $0.404^{*}$ & 0.206 & 0.128 & 0.731 \\
Northern sites only (1952-2003) & & & & 0.757 \\
$\delta^{13} \mathrm{C}$ latewood & $0.509^{* *}$ & 0.012 & 0.656 & 0.612 \\
$\delta^{13} \mathrm{C}$ middlewood & 0.345 & 0.011 & 0.598 & \\
\hline
\end{tabular}

trends the data, see above). The EPS values were also lower for $\delta^{13} \mathrm{C}$ than for $\delta^{18} \mathrm{O}$ time series between sites. If we excluded the most southerly and most distant site (Sonoma is $250 \mathrm{~km}$ south of Arcata) from the analysis, correlation coefficients were improved (Table 3), indicating that environmental forcing of tree-ring $\delta^{13} \mathrm{C}$ variation may not be as regionally coherent as that for $\delta^{18} \mathrm{O}$ variation. In addition, variability in absolute $\delta^{13} \mathrm{C}$ values in tree-ring cellulose does not seem to be related to particular site locations. The Prairie Creek and Arcata sites are both coastal and within $70 \mathrm{~km}$ of each other and yet their $\delta^{13} \mathrm{C}$ values are the most widely separated of the four sites (Figure 6). The absolute amount of carbon isotope discrimination may be a function of local microclimate, whereas inter-annual variability may be influenced by regional climate drivers.

\section{DISCUSSION}

In order for tree-ring isotope chronologies to serve as proxies for climate reconstruction, significant inter-annual variation and coherence in that variation between trees must be established. Isotopic time series that are relatively uniform are analogous to complacent growth for ringwidth studies in that little useable information can be extracted (Fritts 1976; Schweingruber 1987; Cook and Kairiukstis 1989). Dendrochronologists therefore often recommend sampling from stressful sites as they are likely to produce sensitive ring- width chronologies (Schweingruber 1987; Stokes and Smiley 1996). Redwood ecosystems would not be considered a particularly stressful environment as evidenced by lush undergrowth and majestic trees, and indeed redwood ring-width time series are relatively complacent (Roden 2008). However, stable-isotope time series produced substantial inter-annual variation (maximum from 2 to $4 \%$ ) indicating sensitivity to common forcing. The contrast between what ring widths cannot tell us and what tree-ring isotope ratios can tell us demonstrates the power of using stable-isotope analysis in dendroclimatology. That is, species and habitats that might be avoided from a ring-width perspective have the potential to provide valuable information using isotope variation. Ancient redwood trees could provide millennial scale tree-ring records, however crossdating cores from ancient trees could be problematic as they contain ring anomalies (Brown and Swetnam 1994). Extending ring-width or isotope time series into the distant past would require sampling entire slabs of downed redwood trees (or archival material) where multiple radii can be measured and ring anomalies followed around the circumference.

Our results also demonstrate that isotope time series satisfy the other requirement for use in dendroclimatology, that of coherence. Coherence between ring-width time series is at the heart of dating and chronology generation (Schweingruber 1987; Stokes and Smiley 1996). It is also critical 

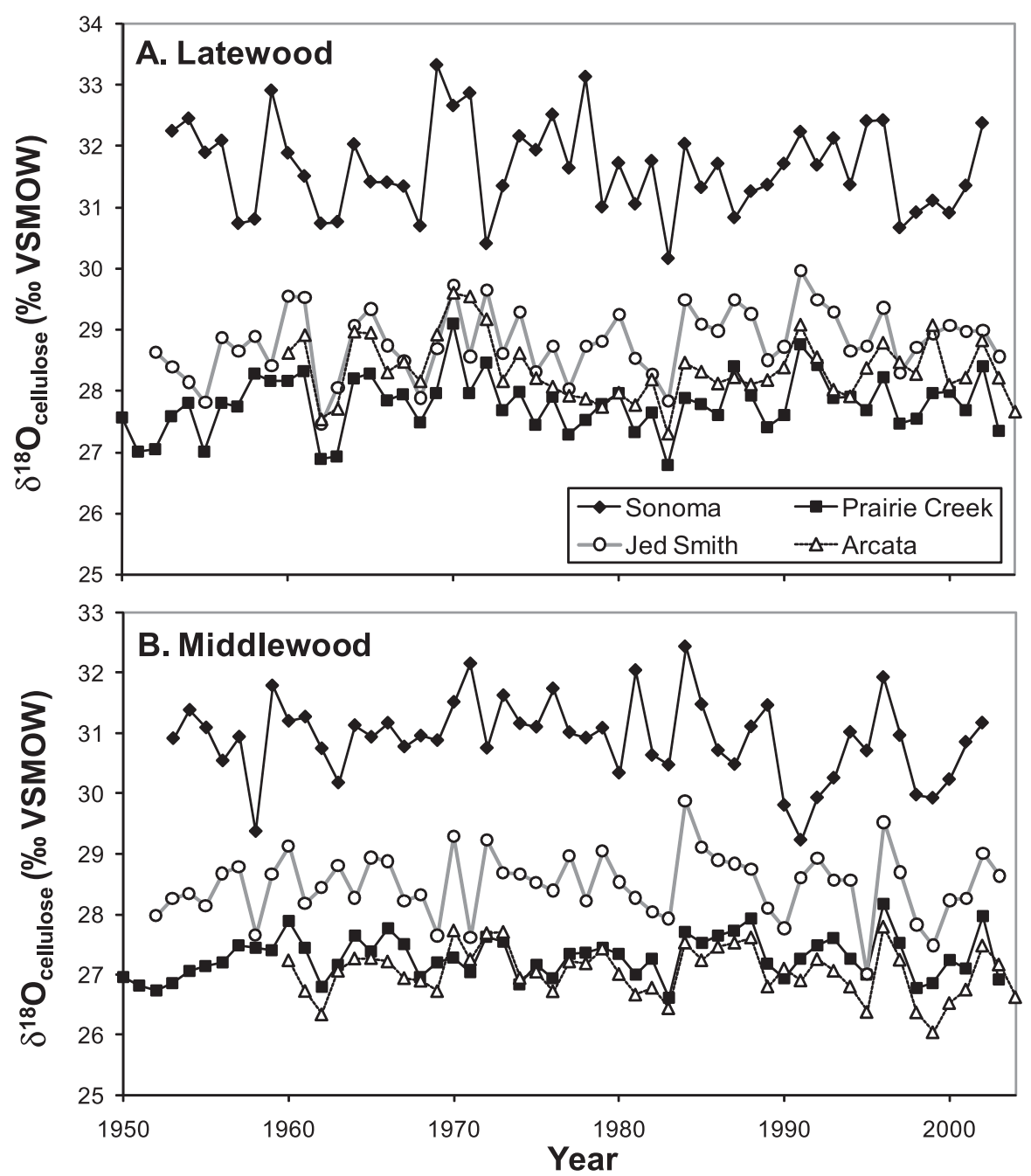

Figure 5. Mean (within site) latewood (A) and middlewood (B) $\delta^{18} \mathrm{O}$ time series for tree-ring cellulose from redwood trees located at four sites. Both series were significantly correlated $(\mathrm{p}<0.01$, see Table 3 ).

for using ring widths for climate reconstruction as it is assumed that trees growing in close proximity ought to be influenced by the same environmental forcing (Fritts 1976; Cook and Kairiukstis 1989). The same is true for isotope time series and many studies have shown within-site and even betweensite coherence in the stable-isotope variation in tree-ring time series (Leavitt and Long 1988, 1989; Leavitt et al. 1985; McCarroll and Pawellek 2001; Ramesh et al. 1985; Roden and Ehleringer 2007). Within-site coherence is to be expected, but it should not be assumed, as microenvironmental differences could have stronger influences than larger-scale climate. Although some of the withinsite correlations from this study were quite good ( $\mathrm{r}$ $>0.7$ ), they were far from perfect, indicating that individual tree microenvironments differ in how they produce "noise" in the correlations. In addition, isotope values are the result of not only environmental inputs but also within-plant fractionation events that can be influenced by plant anatomical and physiological attributes (e.g. stomatal conductance, Farquhar et al. 1982, 1989; Gessler et al. 2009). Within-site correlations of $\delta^{13} \mathrm{C}$ time series may have been lower (and for the Prairie Creek site not significant) than for $\delta^{18} \mathrm{O}$ 

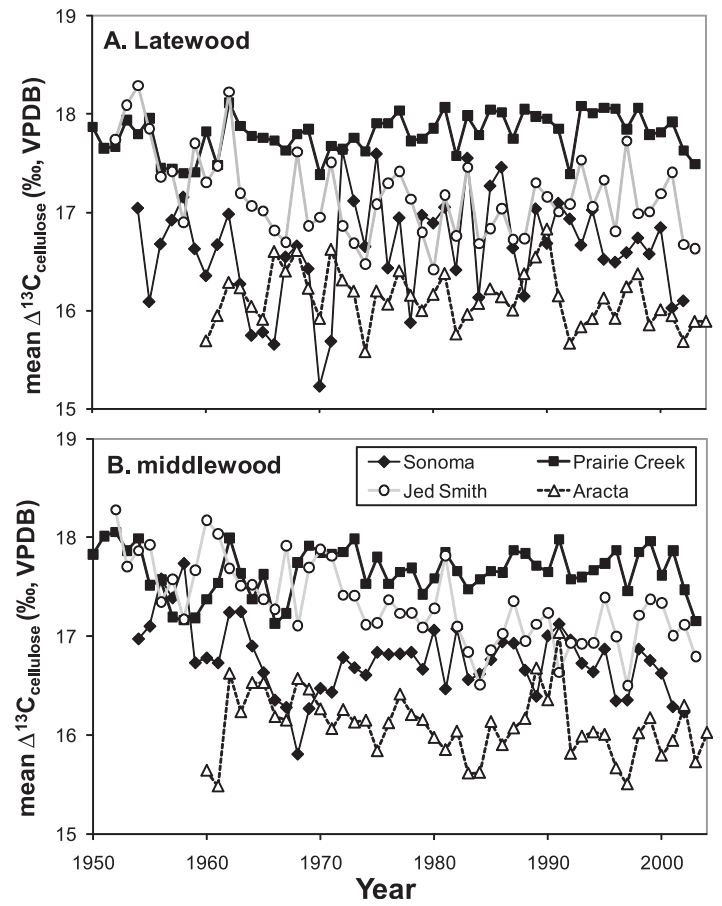

Figure 6. Mean (within site) latewood (A) and middlewood (B) $\Delta^{13} \mathrm{C}$ time series for tree-ring cellulose from redwood trees located at four sites. The latewood $\Delta^{13} \mathrm{C}$ time series were significantly correlated ( $\mathrm{p}<0.05$, see Table 3 ).

time series because carbon isotope fractionation is highly dependent on physiological attributes (e.g. photosynthetic rates and stomatal conductance). The lower values of EPS for $\delta^{13} \mathrm{C}$ comparisons also indicate less confidence regarding common forcing for $\delta^{13} \mathrm{C}$ than for $\delta^{18} \mathrm{O}$ time series. Because our investigations did not focus on decoupling environmental from physiological impacts on the isotope ratios in the tree rings we investigated, we cannot address these issues here.

Our results also indicated that using statistical programs that detrend long-term variation is more important for testing coherence of carbon than for oxygen isotope time series. Correlation coefficients did not change much for $\delta^{18} \mathrm{O}$ time series whether they were detrended (using COFE$\mathrm{CHA}$ ) or not. However, $\delta^{13} \mathrm{C}$ time series can produce erroneous correlations unless corrected for changes in $\delta^{13} \mathrm{C}$ of atmospheric $\mathrm{CO}_{2}\left(\Delta^{13} \mathrm{C}\right.$, see also McCarroll et al. 2009) or a program that eliminates low-frequency variation is utilized (e.g. COFECHA, Grissino-Mayer 2001). Thus, long $\delta^{18} \mathrm{O}$ time series that have not been detrended (and $\delta^{13} \mathrm{C}$ if changes in atmospheric $\mathrm{CO}_{2}$ are accounted for) from ancient redwood slabs have the potential to capture climate information at all temporal frequencies.

The strength of coherence did not substantially differ between latewood and middlewood for $\delta^{18} \mathrm{O}$ time series. However, middlewood $\delta^{13} \mathrm{C}$ timeseries correlations were consistently lower than latewood $\delta^{13} \mathrm{C}$ time series (Table 1). Roden et al. (2009) speculated that middlewood might be laid down in mid- to late-spring and may represent the clearest isotopic signatures for spring conditions because initial earlywood ring production can have substantial carry-over effects via the utilization of the previous year's carbohydrate from storage (Kagawa et al. 2005, 2006). It is possible that summer environmental conditions exert a stronger influence on carbon isotope fractionation than during spring when other factors (physiological) could play a more important role.

A novel feature of this study was to test isotopic variation in many trees along a transect in a single watershed. Isotope dendroclimatology studies that use locations with significant topographic features and potential geographic modification of environmental inputs (e.g. fog movement, drip, and ceiling height may be affected by orographic features) would benefit from developing sampling strategies based on such information. Our results suggest that topographic features do not significantly affect tree-ring cellulose $\delta^{13} \mathrm{C}$ or latewood $\delta^{18} \mathrm{O}$ values. However, middlewood $\delta^{18} \mathrm{O}$ values were higher if the trees were located in the gully than if they were located on a slope above the gully. Whether this difference represents the incorporation of oxygen from a more enriched water source or is the result of increased evaporative enrichment in the gully is unknown at this time.

Significant correlations between latewood and middlewood $\delta^{18} \mathrm{O}$ time series from four distinct sites that span a distance of over $300 \mathrm{~km}$ suggests that regional climate forcing influences the isotopic composition of redwood tree rings. This forcing may be related to conditions that modify annual hydrologic inputs that are isotopically distinct (i.e. precipitation versus fog, Aravena 
et al. 1989; Ingraham and Matthews 1995; Dawson 1998) or that modify isotopic fractionation within the tree (e.g. humidity effects on leaf evaporative enrichment, Lipp et al. 1996; Roden and Ehleringer 1999b). The strong coherence of between-site $\delta^{18} \mathrm{O}$ time series highlights their potential as proxy records that can be used for paleo-climate reconstruction. Other studies have also found coherence in isotope time series for multiple sites (Leavitt and Long 1988, 1989; Leavitt et al. 1985; McCarroll and Pawellek 2001; Roden et al. 2009).

The lower between-site correlations for $\delta^{13} \mathrm{C}$ indicate that climate forcing may not be as regionally coherent for $\delta^{13} \mathrm{C}$ as for $\delta^{18} \mathrm{O}$ time series. Carbon isotope fractionation is primarily dependent on chloroplast $\left[\mathrm{CO}_{2}\right]$ that is influenced by leaf-level supply (stomatal and mesophyll conductance) and demand (photosynthesis) functions (Farquhar et al. 1982; O'Leary et al. 1992). Regional climate factors such as fog frequency and intensity can influence $\delta^{13} \mathrm{C}$ fractionation by increasing supply (via greater stomatal opening under high humidity) and reducing demand (lower light reduces photosynthesis). However, such simple climate drivers will be complicated by other factors and by microclimatic variation that can occur across sites and even within a single tree. For example, drought could modify stomatal set points, and changes in canopy position (tree fall gap) would influence light penetration. The idea that $\delta^{13} \mathrm{C}$ values may be more dependent on micro-site variation than $\delta^{18} \mathrm{O}$ values is also supported by the observation that absolute $\delta^{13} \mathrm{C}$ values differed widely between proximate sites. Roden et al. (2009) also found absolute $\delta^{13} \mathrm{C}$ values differed widely even between trees at the same site. Although absolute isotope values are not as critical as coherence in patterns of interannual variation for climate reconstruction, these differences imply that climate drivers impose variation onto a baseline level of isotope fractionation that depends on microclimate and tree physiological properties. Between-site correlations were improved if the furthest site (Sonoma) was excluded from the analysis, suggesting that subregional climate variations may be important for isotopic values within far northern California.
Thus, in order to effectively use $\delta^{13} \mathrm{C}$ time series for climate reconstruction, replication is essential.

Significant correlations were also observed for the difference between latewood and middlewood isotope time series (Table 3). We have shown previously (Roden et al. 2009) that tree rings of redwood possess substantial intra-annual variability and coherent seasonal changes in $\delta^{18} \mathrm{O}$ and to a lesser extent $\delta^{13} \mathrm{C}$. For specific years these differences in $\delta^{18} \mathrm{O}$ from spring to summer can be as high as $4 \%$ or a low as $0 \%$, and coherence between replicate trees within a site and between distant sites argues strongly that this variation is associated with regional climate forcing and may be another valuable proxy for climate reconstruction.

In Figure 7 the mean (relative) $\delta^{18} \mathrm{O}$ values for all sites were plotted for latewood, middlewood and their difference to present a general 50year pattern of isotopic variation. The latewoodmiddlewood results are absolute rather than relative values as they are already corrected for site differences in their formulation. Particular years containing significant excursions in either latewood, middlewood or their difference are marked with vertical lines to highlight interannual variability (Figure 7). For example, the difference between latewood and middlewood for 1983 and 1984 were identical and nearly 0\%, but latewood and middlewood $\delta^{18} \mathrm{O}$ values for those years were quite different. Both 1970 and 1999 produced large differences between latewood and middlewood, but the cause in 1970 was highly enriched $\delta^{18} \mathrm{O}$ in the latewood portion whereas in 1999 it was highly depleted $\delta^{18} \mathrm{O}$ in the middlewood portion (Figure 7). This analysis demonstrates that seasonally resolved isotopic data has the potential to tease out interesting inter-annual differences that would be obscured if only the entire ring is analyzed. Such data provide the opportunity for a comparison between spring and summer climate variables to understand the driving force(s) for $\delta^{18} \mathrm{O}$ (and $\delta^{13} \mathrm{C}$ ) variation.

It is beyond the scope of this paper to present a detailed analysis of potential climate drivers for isotopic variation in redwood tree-ring cellulose. However, a number of climate features appear correlated with stable-isotope variation in red- 

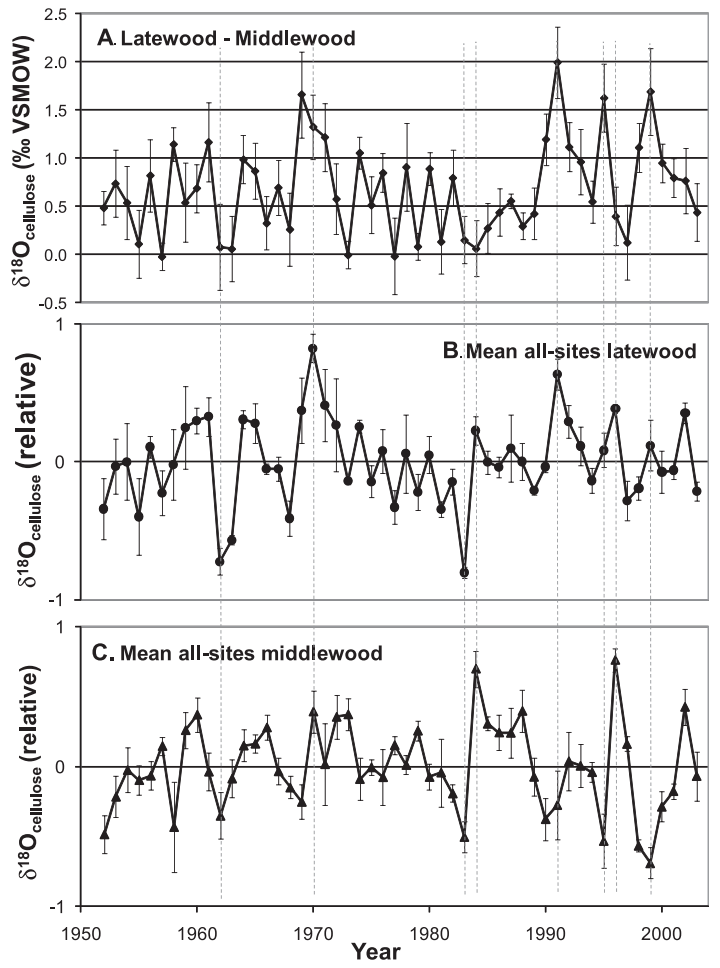

Figure 7. Mean (all sites) latewood-middlewood (A), relative latewood (B) and relative middlewood (C) $\delta^{18} \mathrm{O}$ time series for tree-ring cellulose from redwood trees. Absolute values and deviations for latewood and middlewood $\delta^{18} \mathrm{O}$ differed between sites, and so they were transformed to relative values (mean $=$ 0 ) for statistical calculations. Time series are of mean values of the four sites and error bars indicate standard error. Vertical lines highlight years with significant excursions.

wood tree rings and show promise for climate reconstruction (Johnstone 2008). Precipitation, fog, atmospheric pressure, air temperature maximums and ocean temperature variation are all part of an integrated set of climate drivers (see Johnstone and Dawson (2010) for a full explanation) and thus isotope time series in redwood tree rings have the potential to capture this climate variation if appropriately applied.

In conclusion, strong within-site and between-site coherence in $\delta^{18} \mathrm{O}$ time series for all segments (latewood, middlewood, and the difference between latewood and middlewood) indicates that common forcing of isotope fractionation in redwood tree rings is regionally coherent and not representative of local conditions only. Although redwood trees could provide long chronologies, they have been underutilized by dendrochronologists because of issues with crossdating and climatic interpretation of ring-width variation. This is the first study to demonstrate that, by using stable-isotope analysis of tree rings, redwood trees have the potential to provide valuable proxy information about climate from this important region. Although significant correlations for $\delta^{13} \mathrm{C}$ time series imply that regional climate information can be extracted from such records, they are also more influenced by local environmental conditions and potentially individual tree physiological traits. Thus, replication of $\Delta^{13} \mathrm{C}$ time series would be required to improve the accuracy of climate reconstructions. Although site topographic factors were found to have minimal effects on regional climate forcing of redwood tree-ring isotopic composition, large differences in tree position (slope, aspect, proximity to streams etc.) should still be avoided as microsite differences may add some noise to the data.

\section{ACKNOWLEDGMENTS}

We thank Paul Brooks and Stefania Mambelli at the Center for Stable Isotope Biogeochemistry (UC Berkeley) for technical assistance with the stable-isotope analyses, SOU students J. Hoffheimer, B. Jaentsch, J. Morales, A. Ottombrino, C. Webber, M. Rosvold, R. Weigel, C. Downie and L. Roden for assistance with sample processing and preparation, Julie Truong and Kevin Ha of UC Berkeley for their assistance in preparing the isotope standards. This project was supported by the National Science Foundation, Collaborative Research in Undergraduate Institutions program (grant \#0330806) and the Save-theRedwood-League (and for access to the Sonoma site). We thank the city of Arcata for access to the Arcata Community Forest site and the Redwood National and State Parks for access to the Prairie Creek and Jed Smith sites.

\section{REFERENCES CITED}

Aravena, R. O., O. Suzuki, and A. Pollastri, 1989. Coastal fog and its relation to groundwater in the IV region of northern Chile. Chemical Geology (Isotope Geoscience Section) 79: 83-91. 
Azevedo, J., and D. L. Morgan, 1974. Fog precipitation in coastal California forests. Ecology 55:1135-1141.

Barbour, M. M., A. S. Walcroft, and G. D. Farquhar, 2002. Seasonal variation in $\delta^{13} \mathrm{C}$ and $\delta^{18} \mathrm{O}$ of cellulose from growth rings of Pinus radiata. Plant, Cell and Environment 25: 1483-1499.

Barbour, M. M., J. S. Roden, G. D. Farquhar, and J. R. Ehleringer, 2004. Expressing leaf water and cellulose oxygen isotope ratios as enrichment above source water reveals evidence of a Péclet effect. Oecologia 138:426-435.

Brandes, E., N. Kodama, H. Rennenberg, K. Whittaker, C. Weston, A. Gessler, C. Keitel, M. A. Adams, and A. Gessler, 2006. Short-term variation in the isotopic composition of organic matter allocated from the leaves to the stem of Pinus sylvestris: Effects of photosynthetic and postphotosynthetic carbon isotope fractionation. Global Change Biology 12: 1922-1939.

Briffa, K. R., and P. D. Jones, 1990. Basic chronology statistics and assessment. In Methods of Dendrochronology: Applications in the Environmental Sciences, edited by E. R. Cook, and L. A. Kairiukstis, pp. 137-152. Kluwer, Norwell, Massachusetts.

Brown, P. M., and T. W. Swetnam, 1994. A cross-dated fire history from coast redwood near Redwood National Park, California. Canadian Journal of Forest Research 24:21-31.

Burgess, S. S. O., and T. E. Dawson, 2004. The contribution of fog to the water relations of Sequoia sempervirens (D. Don): Foliar uptake and prevention of dehydration. Plant, Cell and Environment 27:1023-1034.

Cook, E. R., and L. A. Kairiukstis, Editors, 1989. Methods of Dendrochronology: Applications in the Environmental Sciences. Kluwer Academic Publishers, Dordrecht, The Netherlands.

Dawson, T. E., 1998. Fog in the California redwood forest: Ecosystem inputs and use by plants. Oecologia 117:476-485.

Edwards, T. W. D., and P. Fritz, 1986. Assessing meteoric water composition and relative humidity from ${ }^{18} \mathrm{O}$ and ${ }^{2} \mathrm{H}$ in wood cellulose: Paleoclimatic implications for southern Ontario, Canada. Applied Geochemistry 1:715-723.

Ewing, H. A., K. C. Weathers, A. M. Elliott, P. H. Templer, T. E. Dawson, M. K. Firestone, and V. K. S. Boukili, 2009. Fog water and ecosystem function: Heterogeneity in a California redwood forest. Ecosystems 12:417-433.

Farquhar, G. D., M. H. O’Leary, and J. A. Berry, 1982. On the relationship between carbon isotope discrimination and the intercellular carbon dioxide concentration in leaves. Australian Journal of Plant Physiology 9:121-137.

Farquhar, G. D., J. R. Ehleringer, and K. T. Hubick, 1989. Carbon isotope discrimination and photosynthesis. Annual Review of Plant Physiology and Plant Molecular Biology 40: 503-537.

Farquhar, G. D., B. K. Henry, and J. M. Styles, 1997. A rapid on-line technique for determination of oxygen isotope composition of nitrogen-containing organic matter and water. Rapid Communications in Mass Spectrometry 11: 1554-1560.

Francey, R. J., C. E. Allison, D. M. Etheridge, C. M. Trudinger, I. G. Enting, M. Leuenberger, R. L. Langenfelds, E. Michel, and L. P. Steele, 1999. A 1000-year high precision record of $\delta^{13} \mathrm{C}$ in atmospheric $\mathrm{CO}_{2}$. Tellus, Series $B$ Chemical and Physical Meteorology 51:170-193.

Fritts, H. C., 1976. Tree Rings and Climate. Academic Press, New York, USA.

Gaudinski, J. B., T. E. Dawson, S. Quideau, E. A. G. Schuur, J. S. Roden, S. E. Trumbore, D. R. Sandquist, S-W. Oh, and R. E. Wasylishen, 2005. Comparative analysis of cellulose preparation techniques for use with ${ }^{13} \mathrm{C},{ }^{14} \mathrm{C}$ and ${ }^{18} \mathrm{O}$ isotopic measurements. Analytical Chemistry 77:7212-7224, doi:10. 1021/ac050548u.

Gessler, A., E. Brandes, N. Buchmann, G. Helle, H. Rennenberg, and R. L. Barnard, 2009. Tracing carbon and oxygen signals from newly assimilated sugars in the leaves to the treering archive. Plant Cell \& Environment 32:780-795.

Gonfiantini, R., and A. Longinelli, 1962. Oxygen isotope compositions of fog and rains from the North Atlantic. Experientia 18:222-223.

Grissino-Mayer, H. D., 2001. Evaluating crossdating accuracy: A manual and tutorial for the computer program COFECHA. Tree-Ring Research 57:209-221.

Hemming, D. L., V. R. Switsur., J. S. Waterhouse, T. H. E. Heaton, and A. H. C. Carter, 1998. Climate variation and the stable carbon isotope composition of tree-ring cellulose: An intercomparison of Quercus robur, Fagus sylvatica and Pinus silvestris. Tellus, Series B 50B:25-33.

Hill, S. A., J. S. Waterhouse, E. M. Field, V. R. Switsur, and T. Ap Rees, 1995. Rapid recycling of triose phosphates in oak stem tissues. Plant, Cell and Environment 18:931-936.

Holmes, R. L., 1983. Computer-assisted quality control in treering dating and measurement. Tree-Ring Bulletin 43:69-78.

Huntley, L. B., D. Doley, D. J. Yayes, and A. Boonsaner, 1997. Water balance of an Australian subtropical rainforest at altitude: The ecological and physiological significance of intercepted cloud and fog. Australian Journal of Botany 45: 311-329.

Ingraham, N. L., and R. A. Matthews, 1995. The importance of fog-drip water to vegetation: Point Reyes Peninsula, California. Journal of Hydrology 164:269-285.

Johnstone, J. A., 2008. Climate Variability of Northern California and Its Global Connections. Ph.D. dissertation, Department of Geography, University of California, Berkeley.

Johnstone, J. A., and T. E. Dawson, 2010. Climatic context and ecological implications of summer fog decline in the coast redwood region. Proceedings of the National Academy of Sciences 107:4533-4538.

Kagawa, A., A. Sugimoto, K. Yamashita, and H. Abe, 2005. Temporal photosynthetic carbon isotope signatures revealed in a tree ring through ${ }^{13} \mathrm{CO}_{2}$ pulse-labelling. Plant, Cell and Environment 28:906-915.

Kagawa, A., A. Sugimoto, and T. C. Maximov, 2006. ${ }^{13} \mathrm{CO}_{2}$ pulse-labelling of photoassimilates reveals carbon allocation within and between tree rings. Plant, Cell and Environment 29:1571-1584.

Kahmen, A., K. Simonin, K. Tu, A. Merchant, A. Callister, R. Siegwolf, T. E. Dawson, and K. Stefan, 2008. Effects of environmental parameters, leaf physiological properties and leaf water relations on leaf water $\delta^{18} \mathrm{O}$ enrichment in different Eucalyptus species. Plant, Cell \& Environment 31:738-751. 
Leavitt, S. W., A. Long, and J. S. Dean, 1985. Tree-ring dating through pattern-matching of stable-carbon isotope time series. Tree-Ring Bulletin 45:1-9.

Leavitt, S. W., and A. Long, 1988. Stable carbon isotope chronologies from trees in the southwestern United States. Global Biogeochemical Cycles 2:189-198.

Leavitt, S. W., and A. Long, 1989. The atmospheric $\delta^{13} \mathrm{C}$ record as derived from 56 pinyon trees at 14 sites in the southwestern U.S. Radiocarbon 31:469-474.

Leavitt, S. W., and S. R. Danzer, 1993. Method for batch processing small wood samples to holocellulose for stablecarbon isotope analysis. Analytical Chemistry 65:87-89.

Leavitt, S. W., W. E. Wright, and A. Long, 2002. Spatial expression of ENSO, drought, and summer monsoon in seasonal $\delta^{13} \mathrm{C}$ of ponderosa pine tree rings in southern Arizona and New Mexico. Journal of Geophysical Research D: Atmospheres 107:(D18) 4349, doi:10.1029/2001JD001312.

Lipp, J., P. Trimborn, T. Edwards, Y. Waisel, and D. Yakir, 1996. Climatic effects on the $\delta^{18} \mathrm{O}$ and $\delta^{13} \mathrm{C}$ of cellulose in the desert tree Tamarix jordanis. Geochimica et Cosmochimica Acta 60:3305-3309.

Loader, N. J., V. R. Switsur, and E. M. Field, 1995. Highresolution stable isotope analysis of tree-rings: Implications of 'microdendroclimatology' for palaeoenvironmental research. The Holocene 5:457-460.

McCarroll, D., and F. Pawellek, 2001. Stable carbon isotope ratios of Pinus sylvestris from northern Finland and the potential for extracting a climate signal from long Fennoscandian chronologies. The Holocene 11:517-526.

McCarroll, D., M. H. Gagen, N. J. Loader, I. Roberston, K. J. Anchukaitis, S. Los, G. H. F. Young, R. Jalkanan, A. Kirchhefer, and J. S. Waterhouse, 2009. Correction of treering stable carbon isotope chronologies for changes in the carbon dioxide content of the atmosphere. Geochimica et Cosmochimica Acta 73:1539-1547.

Oberlander, G. T., 1956. Summer fog precipitation on the San Francisco peninsula. Ecology 37:851-852.

Ogle, N., and F. G. McCormac, 1994. High resolution $\delta^{13} \mathrm{C}$ measurements of oak show a previously unobserved spring depletion. Geophysical Research Letters 21:2373-2375.

O’Leary, M. H., S. Madhavan, and P. Paneth, 1992. Physical and chemical basis of carbon isotope fractionation in plants. Plant, Cell \& Environment 15:1099-1104.

Poussart, P., M. N. Evans, and D. P. Schrag, 2004. Resolving seasonality in tropical trees: Multi-decade, high resolution oxygen and carbon isotope records from Indonesia and Thailand. Earth and Planetary Science Letters 218:301-316.

Ramesh, R., S. K. Bhattacharya, and K. Gopalan, 1985. Dendroclimatological implication of isotope coherence in trees from Kashmir Valley, India. Nature 317:802-804.

Robertson, I., V. R. Switsur, A. H. C. Carter, A. C. Barker, J. S. Waterhouse, K. R. Briffa, and P. D. Jones, 1997. Signal strength and climate relationships in the ${ }^{13} \mathrm{C} /{ }^{12} \mathrm{C}$ ratios of tree ring cellulose from oak in east England. Journal of Geophysical Research 102:19507-19516.

Robertson, I., J. S. Waterhouse, A. C. Barker, A. H. C. Carter, and V. R. Switsur, 2001. Oxygen isotope ratios of oak in east England: Implications for reconstructing the isotopic com- position of precipitation. Earth and Planetary Science Letters 191:21-31.

Roden, J. S., and J. R. Ehleringer, 1999a. Observations of hydrogen and oxygen isotopes in leaf water confirm the Craig-Gordon model under wide-ranging environmental conditions. Plant Physiology 120:1165-1173.

Roden, J. S., and J. R. Ehleringer, 1999b. Hydrogen and oxygen isotope ratios of tree-ring cellulose for riparian trees grown long-term under hydroponically controlled environments. Oecologia 121:467-477.

Roden, J. S., G. Lin, and J. R. Ehleringer, 2000. A mechanistic model for interpretation of hydrogen and oxygen isotope ratios in tree-ring cellulose. Geochimica et Cosmochimica Acta 64:21-35.

Roden, J. S., and J. R. Ehleringer, 2007. Summer precipitation influences the stable oxygen and carbon isotopic composition of tree-ring cellulose in Pinus ponderosa. Tree Physiology 27: 491-501.

Roden, J. S., 2008. Crossdating of tree-ring $\delta^{18} \mathrm{O}$ and $\delta^{13} \mathrm{C}$ time series. Chemical Geology 252:72-79. doi:10.1016/j.chemgeo. 2008.01.007.

Roden, J. S., J. Johnstone, and T. E. Dawson, 2009. Intraannual variation in the stable oxygen and carbon isotope ratios of cellulose in tree rings of coast redwood (Sequoia sempervirens). The Holocene 19:189-197.

Saurer, M., U. Siegenthaler, and F. Schweingruber, 1995. The climate-carbon isotope relationship in tree rings and the significance of site conditions. Tellus 47B:320-330.

Schleser, G. H., G. Helle, A. Lücke, and H. Vos, 1999. Isotope signals as climate proxies: The role of transfer functions in the study of terrestrial archives. Quaternary Science Reviews 18:927-943.

Schweingruber, F. H., 1987. Tree-rings: Basic Applications to Dendrochronology. D. Reidel (Kluwer), Dordrecht, The Netherlands.

Simonin, K. S., L. S. Santiago, and T. E. Dawson, 2009. Fog interception by Sequoia sempervirens (D. Don) crowns decouples physiology from soil water deficit. Plant Cell \& Environment 32:882-892.

Stewart, G. R., M. H. Turnbull, S. Schmidt, and P. D. Erskine, 1995. ${ }^{13} \mathrm{C}$ natural abundance in plant communities along a rainfall gradient: A biological integrator of water availability. Australian Journal of Plant Physiology 22:51-55.

Stokes, M. A., and T. L. Smiley, 1996. An Introduction to TreeRing Dating. The University of Arizona Press, Tucson, USA.

Treydte, K., G. H. Schleser, G. Helle, D. C. Frank, M. Winger, G. H. Haug, and J. Esper, 2006. Millenium-long precipitation record from tree-ring oxygen isotopes in northern Pakistan. Nature 440:1179-1182.

Warren, C. R., J. F. McGrath, and M. A. Adams, 2001. Water availability and carbon isotope discrimination in conifers. Oecologia 127:476-486.

White, J. W. C., J. R. Lawrence, and W. S. Broecker, 1994. Modeling and interpreting $\mathrm{D} / \mathrm{H}$ ratios in tree-rings: A test case of white pine in northeastern United States. Geochimica Cosmochimica Acta 58:851-862.

Wigley, T. M. L., K. R. Briffa, and P. D. Jones, 1984. On the average value of correlated time series, with applications in 
dendroclimatology and hydrometeorology. Journal of Climate and Applied Meteorology 23:201-213.

Wright, W. E., S. W. Leavitt, and A. Long, 1999. ENSO teleconnections: Eastern Pacific Sea Surface temperature correlations with $\mathrm{d}^{18} \mathrm{O}$ in southeastern Arizona precipitation and tree cellulose. Proceedings of the 15th Pacific Climate (PACLIM) Workshop, edited by R. Wilson, and L. Buffaloe, April 27-30, 1998. Technical Report 64 of the Interagency Ecological Program for the Sacramento-San Joaquin Estuary, California Department of Water Resources, pp. 97-109. Wright, W. E., and S. W. Leavitt, 2006. Boundary layer humidity reconstruction for a semiarid location from tree- ring cellulose $\delta^{18} \mathrm{O}$. Journal of Geophysical Research - D 111: $1-9$.

Yapp, C. J., and S. Epstein, 1982. Climatic significance of the hydrogen isotope ratios in tree cellulose. Nature 297:636-639. Young, G. H. F., D. McCarroll, N. J. Loader, and A. J. Kirchhefer, 2010. A 500-year record of summer near-ground solar radiation from tree ring stable carbon isotopes. The Holocene 20:315-324.

Received 22 July 2010; accepted 5 February 2011. 